\title{
Gastrointestinal haemorrhage from a jejunal gangliocytic paraganglioma
}

\author{
W Aung, H J Gallagher, W P Joyce, D Bouchier Hayes, M Leader
}

\begin{abstract}
A case of jejunal gangliocytic paraganglioma is reported in a 54 year old woman who presented with brisk melaena. The tumour was not encapsulated, involved the mucosa and submucosa, and was composed of epithelial nests, spindle cells, and ganglion cells. These cells were mixed, giving carcinoidlike, paraganglioma-like, and ganglioneuroma-like patterns in different areas of the tumour. The lesion was excised locally and recovery was uneventful. Only four previous cases have been reported at this site.

(F Clin Pathol 1995;48:84-85)
\end{abstract}

Keywords: Gangliocytic paraganglioma, jejunum.

Department of

Histopathology,

Beaumont Hospital, Dublin, Ireland

W Aung

W P Joyce

$M$ Leader

Department of

Surgery

H J Gallagher

D Bouchier Hayes

Correspondence to:

Dr W Aung, Department of Pathology, Kings County

Hospital Center, 451

Clarkson Avenue, Brooklyn, New York 11203, USA.

Accepted for publication 7 June 1994
Figure 1 A: Carcinoidlike area with a ribbon-like pattern. B: Paragangliomalike area. Note the absence of pleomorphism or mitoses in both areas

haematoxylin and eosin $\times 200$ ) ried out following resuscitation was normal. Sigmoi-doscopy was abandoned at $15 \mathrm{~cm}$ because of melaena. A technitium labelled colloid scan was of no help. Angiography was considered, but the patient's condition deteriorated and a decision to proceed to surgery was made.

At laparotomy, blood was observed in the small bowel extending to the proximal jejunum where a lesion was palpated intraluminally. Jejunostomy was performed and a pedunculated lesion measuring $7 \times 4 \times 3 \mathrm{~cm}$ was found in the proximal jejunum just distal to duodeno-jejunal flexure. There was an actively spurting arterial bleeder on the surface. The lesion was excised locally and postoperative recovery was uneventful.

\section{Pathology}

The tumour measured $7 \times 4 \times 3 \mathrm{~cm}$, was lobulated and covered with mucosa. The cut surface was solid and pale yellow. Histologically, the tumour was not encapsulated and involved the muscosa and submucosa. It was composed of epithelial nests, spindle cells, and ganglion cells. They were admixed in a varied manner, giving carcinoid-like, paraganglioma-like, and ganglioneuroma-like patterns in different areas of the tumour. Carcinoid-like areas presented as compact nests or trabeculae with indistinct cytoplasmic margins and oval nuclei (fig 1A).

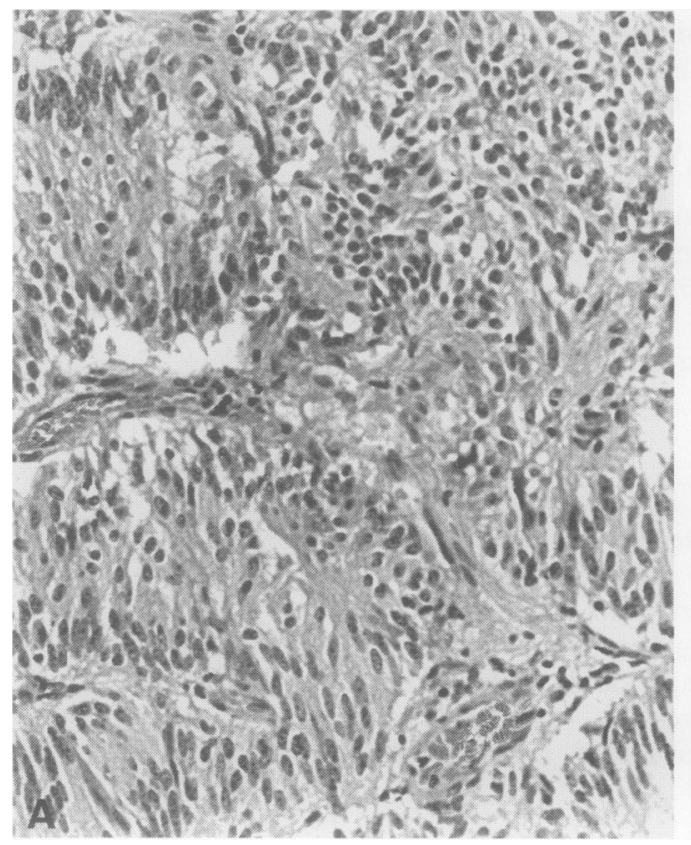

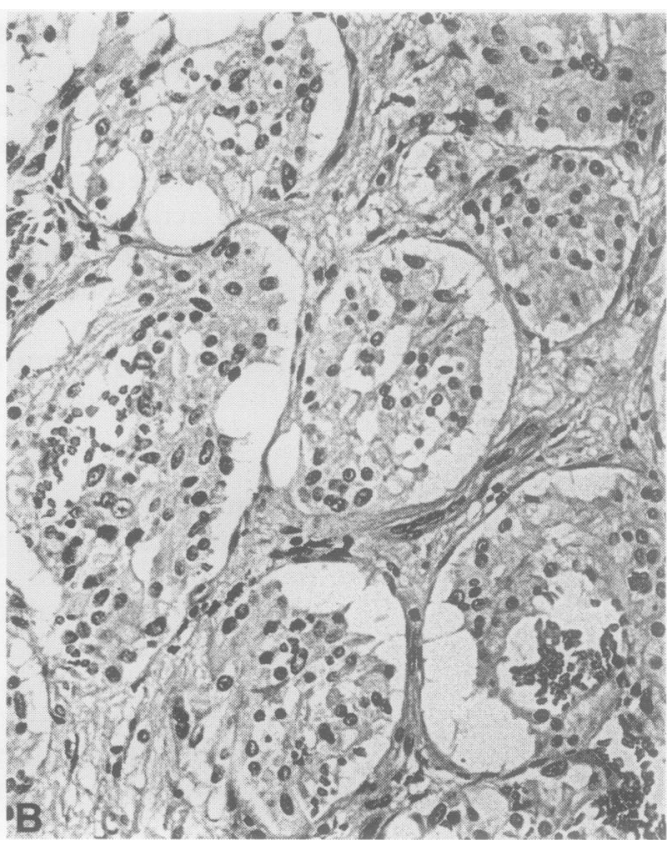


Figure 2 A: Spindle cell areas with ganglion cells (arrowhead)

(haematoxylin and eosin $\times 200$ ). B: Positive staining for $S-100$ protein was observed in spindle cells (arrowhead), with negative staining for carcinoid-like cells. C: Staining for neurone specific enolase was negative in spindle cells and positive for carcinoidlike and ganglion cells (arrowhead)

(haematoxylin and eosin $\times 100$ ).
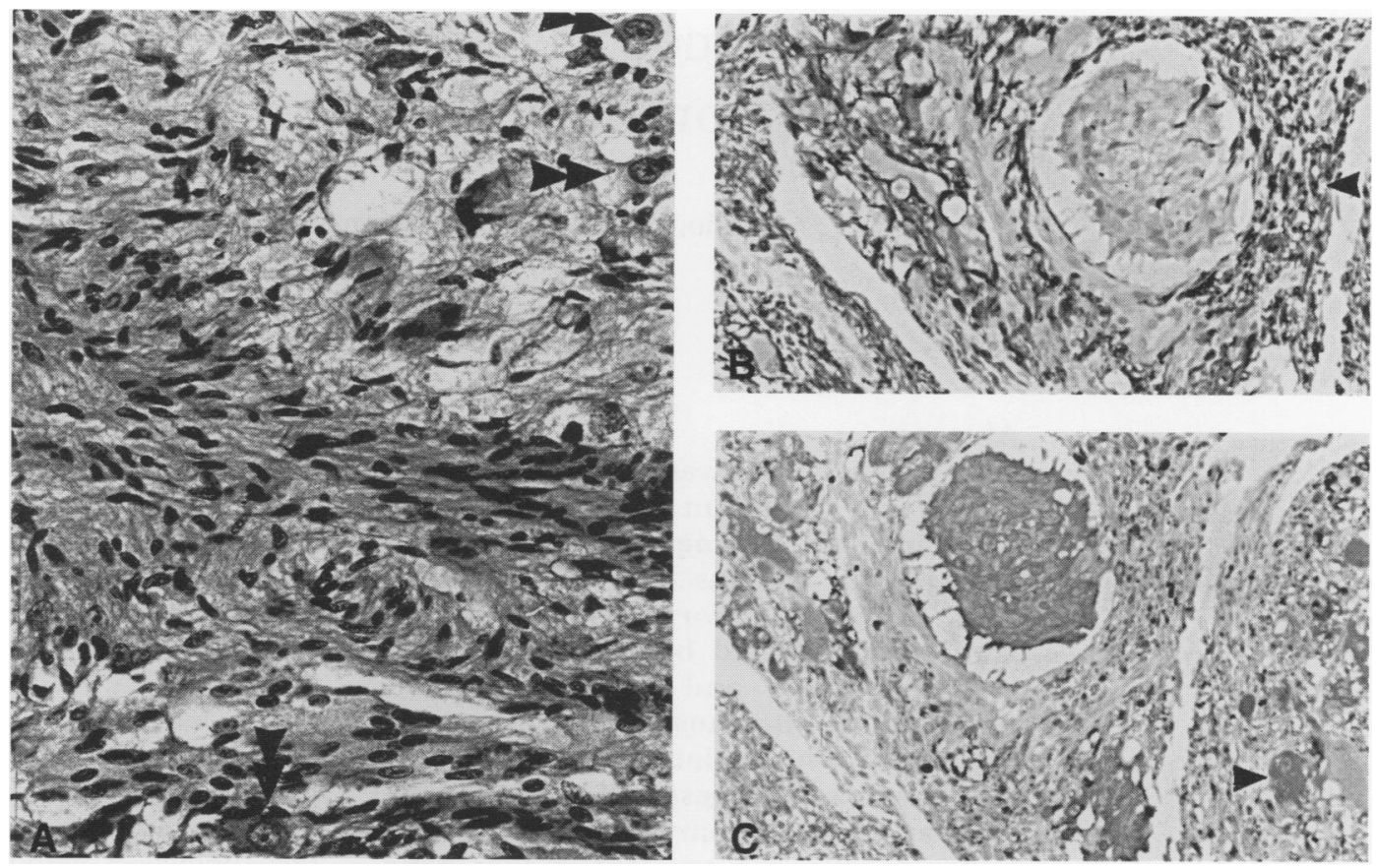

Ganglioneuroma-like areas presented as ganglion cells admixed with spindle cells and delicate fibrous tissue (fig 2A). Paraganglioma-like patterns showed rounded nests of epithelioid cells surrounded by spindle cells (fig 1B).

Immunohistochemically, carcinoid-like nests were positive on staining for chromogranin, synaptophysin, somatostatin, and neurone specific enolase but negative for S-100 protein; spindle cells were positive for S-100 protein but negative for other markers; and ganglion cells were positive for neurone specific enolase and synaptophysin but negative for S-100 protein and chromogranin (fig 2). On electron microscopy, cells from carcinoid-like areas had numerous cytoplasmic dense core granules. Based on the above, the patient was diagnosed as having gangliocytic paraganglioma.

\section{Discussion}

Gangliocytic paragangliomas are peculiar tumours occurring almost exclusively in the second part of the duodenum, especially around the ampulla of Vater. The microscopic appearance of these tumours is distinctive with no exact counterpart elsewhere in the body. ${ }^{1}$ Only four previous cases have been reported in the jejunum. ${ }^{2-4}$ Their histogenesis is unclear. They have been regarded as hamartomatous, hyperplastic or neoplastic proliferations of endodermal/neuroectodermal complexes. ${ }^{134}$ They usually present in the sixth decade of life with gastrointestinal haemorrhage or pain and rarely as gastric outlet or biliary obstruction. ${ }^{23}$ Some were discovered incidentally at surgery or necropsy. ${ }^{2}$ In all but one case the tumours were localised. All, including the one with lymph node metastasis, were cured by local excision. Neoplasms histologically similar to gangliocytic paragangliomas have been observed in the central nervous system and have been referred to as paraganglioma/ganglioneuroma of the filum terminale. ${ }^{5}$

1 Rosai J. Ganglocytic paraganglioma. In: Ackerman's Surgical Pathology. 7th edn. St Louis: CV Mosby,

2 Burke AP, Heiwig EB. Gangliocytic paraganglioma of the small intestine [abstract]. Lab Invest 1988;58:13A.

3 Reed RJ, Daroca PJ, Harkin JC. Gangliocytic paraganglioma. Am f Surg Pathol 1977;1:207-16.

4 Grouls V, Pickartz H, Reis HE. Pedunculated polypoid gangliocytic paraganglioma of the apparent jejunal loop of a Billroth II stomach. Leber Magen Darm 1987:17. $327-33$

5 Weller RO, ed. Tumours of the nervous system. In: Colour Atlas of Neuropathology. Oxford: Oxford University Press, 1984:74-5. 